DOI 10.36074/30.10.2020.v3.35

\title{
СУЧАСНИЙ НАПРЯМ В ІНДУСТРІЇ МОДИ: ВІРТУАЛЬНИЙ ОДЯГ
}

ORCID ID: 0000-0003-4075-2218

НАУКОВО-ДОСЛІДНА ГРУПА:

Векліч Анастасія Миколаївна

аспірант фракультету дизайну

Київський національний університет технологій та дизайну

ORCID ID: 0000-0001-6760-3728

Пашкевич Калина Лівіанівна

д-р. техн. наук, професор, профресор кафедри ергономіки і дизайну

Київський національний університет технологій та дизайну

ORCID ID: 0000-0001-5665-0131

Колосніченко Олена Володимирівна

д-р. мист., доцент, професор кафредри художнього моделювання костюма

Київський національний університет технологій та дизайну

Касс Богдан Вікторович

аспірант фракультету дизайну

Київський національний університет технологій та дизайну

Юхимчук Анастасія Олександрівна

здобувач вищої освіти факультету дизайну

Київський національний університет технологій та дизайну

УКРАÏHA

Ідея віртуального одягу не $\epsilon$ новою і вже досить давно використовується розробниками комп'ютерних ігор, але в останні роки вона отримала новий напрям в розвитку - створення цифррового одягу для реальних людей. Новий стан речей в світі в умовах екологічної кризи та пандемії змусив багатьох споживачів переглянути свою споживчу поведінку, а виробників шукати альтернативу традиційному виробництву і продажам в цифрових технологіях та цифровій моді.

Цифрову моду співзасновниця будинку цифровоої моди The Fabricant, Amber Jae Slooten, визначає як: «...все, що пов'язано з модою за межами фрізичного світу - мода, яку ви можете носити зі своєю цифровий ідентичністю» [4]. Таким чином, цифровий одяг - це речі, яких фактично не існує в реальності, при цьому задум дизайнера відтворюють в комп'ютерній програмі, а потім накладають на фотографію людини за допомогою спеціально розробленого програмного забезпечення. Ці програми дають можливість створювати одяг, взуття, головні убори та аксесуари, надавати їм форми та текстури, які неможливо реалізувати і складно носити в реальному житті.

Одним з перших розробників цифрових образів стала 3D-дизайнерка Cat Taylor (Англія). Перші публікації її робіт з'явились на сторінці Instagram в 2015 р. [1]. Основним напрямом іï роботи $€$ розробка 3D-моделей речей для інтерактивних вітрин та створення віртуального матеріалу для рекламних кампаній світових fashion-брендів таких як: Balenciaga, Vetements, A-Cold-Wall тощо. 
В 2018 році креативна агенція Virtue (Данія) та бренд Carlings (Норвегія) спільно випустили першу комерційну колекцію цифрових образів adDRESS_THE_FUTURE (Рис. 1) [2]. Однією з цілей створення віртуальної колекції було привернути увагу до негативного впливу індустрії моди на навколишнє середовище.

Технології цифрового дизайну використовують не тільки для створення нових віртуальних моделей, а й для відтворення існуючих виробів. Так бренд одягу Hanifa [5] завдяки віртуальному показу моделей в Instagram зміг прорекламувати свою нову колекцію, реальний показ якої був скасований через пандемію.

На відміну від цифрового, AR-одяг існує як фрізичний об'єкт і на ньому розміщено зображення для створення доповненої реальності (англ. augmented reality - доповнена реальність, звідси AR-одяг). Візуальні ефекти стають видимими на екрані смартфону після запуску спеціальної програми при наведені камери на AR-одяг.

B 2019 році Carlings першими розробили інтерактивну футболку Last Statement T-shirt [6]. На ній розміщено невеликий принт, що дозволяє за допомогою спеціального додатку на смартфоні накладати на виріб певний набір різних анімованих зображень (Рис. 2).

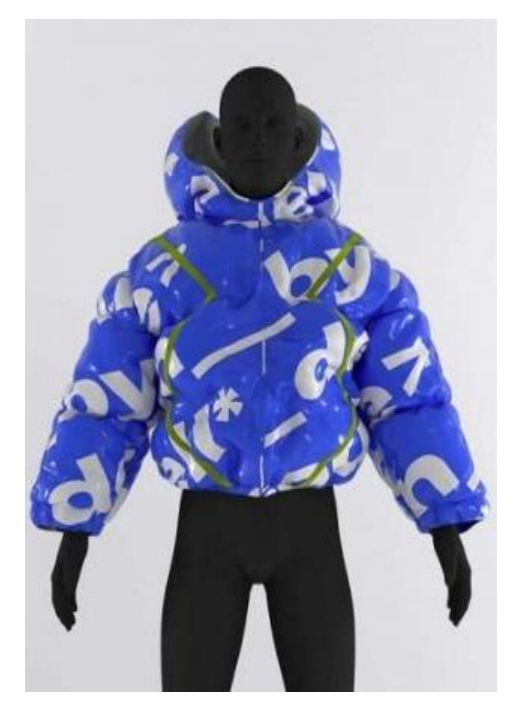

Рис. 1. Модель одягу 3 першої цифрової колекції Carlings
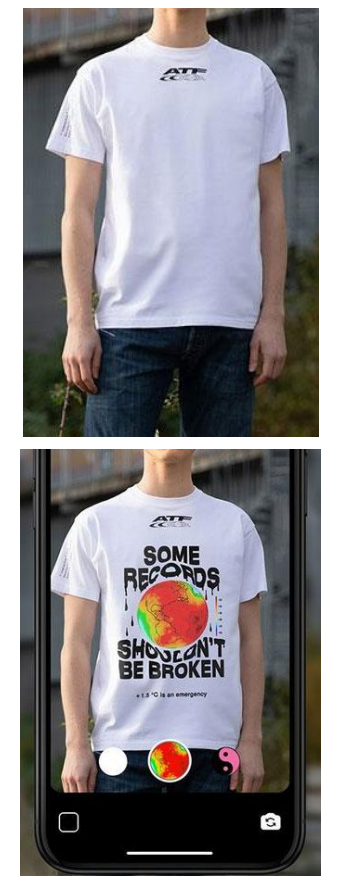

Рис. 2. Інтерактивна футболка Last

Statement T-shirt від бренду Carlings

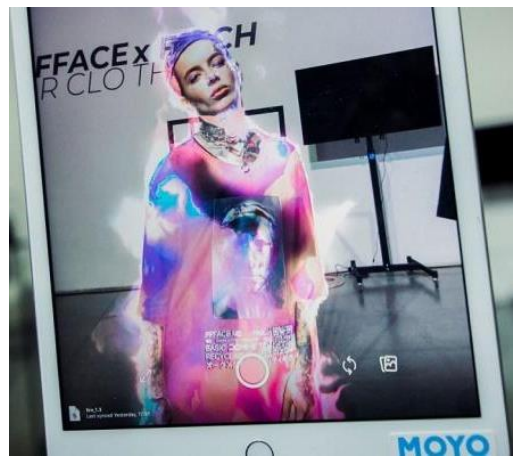

Рис. 3. Моделі ARодягу FFFACE x FINCH

Український бренд одягу FINCH спільно зі студією з розробки продуктів доповненої реальності FFFACE в 2020 році випустили капсульну колекцію ARодягу. Світшот і футболка з капсули FFFACEXFINCH мають віртуальну 3Dанімацію (Рис. 3) [7]. Перевагами розробки є можливість активацї анімації без використання додаткового програмного забезпечення, крім додатку Instagram, a всі оновлення і розширення візуальних ефектів не потребують внесенння змін в одяг. 
3 розвитком значення соціальних мереж в житті людей значно зросла кількість покупок одягу виключно для створення фото- та відеоматеріалу. Річ одягають один-два рази і повертають назад - до магазину, тримають на полиці в шафрі або викидають. За таких обставин створення цифрового та AR-одягу набуває, крім практичного, також і екологічного змісту, адже створення цифрового одягу не вимагає ні витрат текстильних матеріалів, ні утилізації відходів, а AR-одяг дає змогу на основі однієї речі отримати кілька візуально різних моделей.

В результаті проведеного аналізу застосування цифрових технологій для створення нових моделей одягу було виділено основні напрями: виробу;

-цифровий одяг, що являється віртуальним 3D-зображенням готового

-AR-одяг, що існує в реальності, але містить зображення, що здатне активувати ефректи доповненої реальності на екрані смартфону.

Висновки. Визначено, що використання цифрових технологій в модній індустрії набувають все більшого застосування. Візуалізація виробів за допомогою програмного забезпечення дала змогу брендам поширювати свої модні ідеї в умовах обмежених можливостей проведення показів. Виділено два напрями створення нових моделей з використанням цифрових технологій: розробка цифрового одягу та AR-одягу 3 доповненою реальністю. Перспективами подальших досліджень $€$ визначення інших напрямів розвитку технологій віртуального одягу в фешн індустрії.

\section{Список використаних джерел:}

[1] Малютина, А. (2020). Что такое виртуальная одежда и сможет ли она заменить реальную. URL: https://style.rbc.ru

[2] Чуйкин, П. (2020). Цифровая одежда: временная мода, эксперименты с внешностью или необходимость будущего? URL: https://kanobu.ru

[3] Kolosnichenko, M.V., Pashkevich, K.L., Krotova, T.F., Yakovlev, M. I., Nikolayeva, T. V., Ostapenko, N. V., ... Vasylieva, I. V. (2020). Fashion design in a multicultural space: Monograph. Košice: Academic Society of Michal Baludansky, UK Technical University of Košice.

[4] Thepowerhouse (2020). The future of self-expression: What is digital fashion? by Amber Jae Slooten of The Fabricant. URL: https://thepowerhouse.group/

[5] Segran, E. (2020). Hanifa's virtual 3D fashion show is haunting, beautiful, and brilliantly executed. https://www.fastcompany.com

[6] Snowden, H. (2019). Lets you change graphics via your smart phone. URL: https://www.highsnobiety.com/

[7] Ukrainian Fashion Week (2020). FINCH випустив капсулу AR-одягу. URL: http://fashionweek.ual 